\title{
Proteolytic and oxidoreductase activity of Treponema denticola ATCC 35405 grown in an aerobic and anaerobic gaseous environment
}

\author{
S.A. Syed, K.K. Mäkinen (*), P.-L. Mäkinen, C.-Y. Chen and Z. Muhammad \\ Departinemt of Biviogic and Materials Sciences, School of Dentistry. \\ The University of Michigan, Ann Arbor, MI 48109 (USA)
}

\begin{abstract}
SUMMAFY
The cells of a human oral spiroche". Treponema denticola ATCC 35405, and of seven clinical isolates of this organism - btained from the subgingival dental plaque of periodontitis patients were studied for their ability to grow in an aerobic and an anaerobic environment, and for their profile of peptidohydrolase and oxidoreductase enzymes. The growth yield of aerobically grown cultures was either comparable to or higher than that of anaerobically grown ones regardless of whether prereduced broth, freshly prepared broth or oxidized broth was used. However, elimination of certain supplements from the growth media resulted in poor growth regardless of the nature of the gaseous environment. The microscopic morphology and motility of the cells were not affected by differences in the gaseous atmosphere. Cuantitative studies on several peptidohydrolase activities suggest that anaerobically grown cells displayed higher specific activity especially toward $\boldsymbol{N \alpha}$-L-prolyl-2-naphthylamine, indicating that increased synthesis of proline iminopeptidase enzymes (or enzyme) of the cells was associated with anaerobic growth conditions. The formation of enzymes hydrolysing $N \alpha$-benzoyl-DLarginyl-2-naphthylamine (and the corresponding $p$-nitroaniline) was not affected to the same extent. Growth experiments suggest that $T$. denticola ATCC 35405 is a facultatively anaerobic spirochete instead of an obligate anaerobe as reported in previous literature. The quantitative enzyme studies suggest that the gaseous growth atmosphere of the cells can exert a selective effect on the activity levels of certain peptidolytic enzymes of this organism. Such effects were not observed when the whole cells were studied by means of qualitative or semi-quantitative enzyme tests. The activities of catalase, peroxidase and superoxide dismutase of the cells were low and variable. Because of this, it was not possible to relate these oxidoreductase activities to the composition of the gaseous atmosphere.
\end{abstract}

Key-words: Oxygen, Stomatology, Treponema denticola: Proteases, Oxidoreductases, Gaseous environment, Dentistry.

Submitted March 3, 1993, accepted April 27, 1993.

(*) Corresponding author. 


\section{INTRODUC,TION}

Oral spirochetes are members of the indigenous oral microbiotat of humans (Loesche, 1988; Barron et al., 1991), and they are undetectable in individuals with excellent oral health. Their numbers and proportions increase and they become predominant in oral infections such as periodontal diseases and acute necrotizing ulcerative gingivitis (Loesche et al., 1992; Locsche, 1988; Simonson et al., 1988; Riviere et al., 1992; Russel, 1992). The cultureable human oral spirochetes have been classified as species of the genus Treponema (Smibert, 1984). In relationship to molecular oxygen, all oral Treponema species have been reported as obligate anaerobes, i.e. organisms which are sensitive to oxygen and do not grow in air or in microaerophilic or capnophilic gaseous conditions. $T$. denticola is one of the oral spirochetes which is considered as an obligate anaerobe (Smibert, 1984, 1985). In this paper, we report that $T$. denticola is instead a facultatively anaerobic spirochete which is capable of growing in partially aerobic and anaerobic environments. We also studied the growth ability of $T$. denticcla reference strain ATCC 35405 and of several clinical isolates of the same species grown in an anaerobic and a room atmosphere. To our knowledge, this is the first report that describes $T$. denticola as a facultatively anaerobic host-associated human oral spirochete.

Congruent with the lack of adequate information about the growth of $T$. denticola under different oxygen environments is the lack of information on how the activity levels of proteolytic (EC 3.4) and oxidoreductase (EC 1) enzymes respond to such changes in the gaseous atmosphere. Previous studies have elucidated the importance of proteolytic activity to $T$. denticola (Mäkinen et al., 1987; Uitto et al., 1988;
Grenier et al., 1990; Mäkinen et al., 1990; Que and Kuramitsu, 1990; Holt and Bramanti, 1991; Mäkinen et al., 1992). Although no chemical studies on the oxidoreductases of $T$. denticola have been carried out, one can assume that the presence or absence of oxygen in the growth environment should have an impact on the activity levels of those enzymes. Consequently, another purpose of this study was to elucidate the activity levels of several proteolytic and oxidoreductase enzymes present in the cells of $T$. denticola ATCC 35405 grown under aerobic and anaerobic gaseous environments.

\section{MATERIALS AND METHODS}

\section{Source and maintenance of the cells}

A total of eight clinical strains of $T$. denticola were used in this stuíy. Seven strains were isolated at this laboratory from the subgingival plaque of periodontitis patients undergoing treatment at the Periodontics Clinic of the University of Michigan Dental School. A reference strain, ATCC 35405, was initially obtained from the American Type Culture Collection. Stock culture suspensions of each strain were prepared in a preservation medium and $1.0-\mathrm{ml}$ aliquots of the suspensions were dispersed in $2.0-\mathrm{ml}$ cryogenic vials and kept in liquid nitrogen. The composition of the preservation medium per $100 \mathrm{ml}$ was as follows: heat-activated rabbit serum, $75 \mathrm{ml}$; MTYGS, $25 \mathrm{ml}$; D-glucose, $6.5 \mathrm{~g}$. The working cultures were maintained either aerobically or anaerobically in $10 \mathrm{ml}$ of an enriched broth (MTYGS) in screw-capped test tubes $(16 \times 125 \mathrm{~mm})$ and subcultures were made every 2 to 3 weeks after the purity of the cultures had been checked by phase-contrast microscopy. MTYGS is a serum-containing enriched medium which has been routinely used in this laboratory in the cultivation and maintenance of oral spirochetes. This medium contains $5 \%$ heatinactivated rabbit serum, short-chain fatty acids (acetic, butyric, valeric, isovaleric and $\mathrm{DL}$ methylbutyric acids), yeastolate, thiamine pyrophosphate, cysteine- $\mathrm{HCl}$, sodium pyruvate, tryp-

$$
\begin{array}{ll}
\mathrm{R} & =\text { prereduced }(\text { broth) } \\
\text { SDS- } & \\
\text { PAGE }= & \text { sodium dodecyl sulphate/polyacrylamide gel elec- } \\
& \text { trophoresis. } \\
\text { SOD } & \text { superoxide dismutase. }
\end{array}
$$

(For BANA. BAPNA, FALGPA, PZ-PLGPA, see "Materials and Methods" - Quantitative enzyme determinations). 
tone (pancreatic digest of casein), heart infustion broth and mineral salts, as described elsewhere in detail (Salvador et al., 1988).

\section{Growth experiments}

Duplicate sets of broth tubes each containing $9.0 \mathrm{ml}$ of MTYGS were itoculated with $1.0-\mathrm{ml}$ aliquots of test cultures obtained from the late log or the stationary phase, and incubated at $35^{\circ} \mathrm{C}$ either in room atmosphere (aerobic cultures) or in an anaerobic glovebox $\left(85 \% \mathrm{~N}_{2}, 5 \% \mathrm{CO}_{2}\right.$ and $10 \%$ $\mathrm{H}_{2}$; anaerobic cultures) for 4 to 7 days. At the end of incubation, the growth yield was determined turbidimetrically at $660 \mathrm{~nm}$. Several experiments were performed using prereduced broth ( $R$ broth), freshly prepared broth ( $F$ broth), unreduced medium kept at room atmosphere (oxidized or $\mathrm{O}$ broth) and freshly prepared broth with serum, but excluding supplements (i.e. fatty acids, gelatin, and cysteine- $\mathrm{HCl}$; $\mathrm{NS}$ broth). The morphology and the motility of the cells were studied microscopically.

\section{Use of rapid enzyme profile system}

The cells grown in various broths under aerobic and anaerobic conditions were characterized using several chromogenic substrates by means of the rapid enzyme profile system (Syed et al., 1984, 1985). The chromogenic and other substrates used in these studies are shown in table 1 . In a routine enzyme assay, $50 \mu \mathrm{l}$ of a $0.05 \%$ substrate solution were dispersed into the microtitre wells of 96-well plates which were prepared in advance and kept frozen at $-20^{\circ} \mathrm{C}$ until used. The cells were harvested from the broths by centrifugation, washed thrice in $0.01 \mathrm{M}$ Hepes-phosphate buffer $(\mathrm{pH} 7.0)$ and resuspended in the same buffer to obtain a turbidity of 4 to $5 \mathrm{ccm}$ pared with McFarland standard (Hendrickson, $1985) ; 100-\mu \mathrm{l}$ aliquots of each test culture were added to the wells containing the enzyme substrates. The microplates were incubated at room atmosphere for $12-14 \mathrm{~h}\left(35^{\circ} \mathrm{C}\right)$. The rate of the hydrolysis of $p$-nitrophenyl derivatives was determined by the apnearance of the yellow chromophore. The reactions in wells containing 6-bromo-2-naphthyl derivatives were read after addition of $0.1 \%$ "Fast Garnet GBC" reagent. A solution of $p$-dimethylaminocinnamaldehyde reagent (Innovative Diagnostic System, Atlanta, GA, USA) was added to wells containing $N$-L-aminoacyl-2-naphthylamines (2-NA) as enzyme substrates. Development of red or purple color after the addition of the reagent was recorded as a positive reaction. The solution for esculin test was prepared according to the method of Qadri et al. (1980) and dispensed in $50-\mu l$ aliquots into the wells. The indole test was performed as described by Karim et al. (1981). The nitrate reduction test was carried out according to Gusberti and Syed (1984), and the catalase test as described in the Manual of Clinical Microbiology (Hendrickson, 1985). The appropriate controls were included in the microplates.

\section{Quantitative enzyme determinations}

The activity of proteolytic er:zymes was also studied using the following substrates: $N \alpha$-Lprolyl-2-NA, Na-L-pyrrolidonyl-2-NA, $N \alpha$-benzoylDL-arginyl-2-NA (BANA), Na-benzoyl-DL-arginyl$p$-nitroaniline (BAPNA), N $\alpha$-hydroxyprolyl-2-NA, $N \gamma$-L-glutamyl-2-NA, azocasein, phenylazobenzyloxycarbonyl-L-prolyl-L-leucylglycyl-L-prolyl-Darginine (PZ-PLGPA; a substrate of microbial collagenases), and 2-furylacryloyl-L-leucylglycyl-Lprolyl-D-arginine (FALGPA; another substrate used in the study of microbial collagenases). These substrates were considered to represent various peptidase activities previously studied and characterized at this laboratory in the cells of oral treponemes (Mäkinen et al., 1987, 1990, 1992). The enzymes for these studies were obtained by treating the cells with an ultrasonic disintegrator (vide infra). The literature detailing the enzyme determinations has been mentioned previously (Mäkinen et al., 1987, 1988, 1990, 1992).

Preliminary studies indicated that among the large number of oxidoreductases present in microorganisms, superoxide dismutase (SOD; EC 1.15.1.1) and catalase (EC 1.11.1.6) activities were considered relevant study objects in the cells of $T$. denticola. Both cell suspensions and cell extracts (vide infra) were used in these studies. The suspensions were treated with toluene (Whitelam and Codd, 1982) for the determination of the SOD activity of whole cells. The SOD activity was measured by means of nitrite formation from hydroxylamine in the preserice of xanthine-xanthine oxidase $\mathrm{O}_{2}^{-}$generation system (Elstner et al., 1983). One SOD unit was defined as the amount of enzyme causing $50 \%$ inhibition under the assay conditions; this procedure is $10-20$ times more sensitive than the original method of McCord and Fridovich (1969). The activity of catalase was assayed by adding enzyme to diluted $\mathrm{H}_{2} \mathrm{O}_{2}$ solution; the loss of absorbance at $240 \mathrm{~nm}$ was recorded for $1 \mathrm{~min}$. The initial (10-20 s) rates were used to calculate the catalase activities. The activity of peroxidase (EC 1.11.1.7) was tested using a mixture of phenol and 4-aminoantipyrene as a substrate (Pine et al., 1984).

\section{Ultrasonic disintegration of cells}

Cell extracts of $T$. denticoia were made by treating $20-30 \mathrm{mg}$ of cells (wet weight) with a "Heat 
Systems-Ultrasonics" (Farmingdale, New York) cell disruptor model $W-225$, using the microtip $(3 \mathrm{~mm}$ end diameter), and keeping the celi suspension in an iced water bath. The mixtures were centrifuged for $20 \mathrm{~min}$ at $20,000 \mathrm{~g}$ and the supernatant solutions were used in the study of oxidoreductases and peptidases.

\section{Fast protein liquid chromatography (FPLC)}

The enzymes wele prepared for FPLC studies by a procedure that differed from the ahove because larger quantities of enzymes were needed. Therefore, the test cultures were grown aerobicaliy and anaerobically in $500 \mathrm{ml}$ of MTYGS broth for 72-96 h. The cells were harvested by centrifugation for $10 \mathrm{~min}$ at $16,500 \mathrm{~g}$ and washed thrice with $10 \mathrm{mM}$ Tris- $\mathrm{HCl}$ pH 7.0 containing $0.1 \mathrm{mM} \mathrm{CaCl}_{2}$. The final cell suspensions were made in $10 \mathrm{ml}$ of the above buffer. These suspensions were treated with the ultrasonic disintegrator for $2 \mathrm{~min}$, chilling the suspension in an iced water bath. The treated suspensions were then centrifuged as above. The FPLC unit (Pharmacia, Uppsala, Sweden), was operated at $22^{\circ} \mathrm{C}$ and equipped for this study with a Mono Q HR5/5 anion exchange column and a Superose 6 gel column. The samples were filtered through ACRO LC25 $0.2-\mu \mathrm{m}$ membranes (Gelman, Ann Arbor MI), and injected into the FPLC system. The proteins were monitored at 234 or $278 \mathrm{~nm}$.

\section{Other procedures}

The chemical protein determinations were carried out according to Bradford (1976). The water used was made with a "Millipore Milli-Q" system and had a resistivity of at least $18 \mathrm{megaohms} / \mathrm{cm}$.

\section{RESULTS}

\section{Growth studies}

The growth yields of the cells determined in the $\mathrm{R}, \mathrm{F}$ and $\mathrm{O}$ broths are shown in figure 1 . The organisms grew well and formed uniform turbidities in these media; the gaseous environments had no apparent effect on the growth yields. The optical densities of culiures grown under aerobic conditions were similar to or higher than those grown under anaerobic conditions. The microscopic morphology and motility of the organisms were comparable. No bizarre-shaped organisms or circular forms were observed in any of the cultures. The growth of the cells in the NS broth is shown in figure ID, which indicates that supplement elimination from the medium displayed poor growth under both gaseous conditions, except for one strain (no. 6). This suggests that the poor growth resulted from the absence of important growth factors in the culture medium. However, the morphology and motility of the organisms was unaffected by supplement elimination.

\section{Enzyme activities tested with the rapid system}

Table I summarizes the results from the rapid enzyme tests. Thirteen out of twenty enzyme reactions were positive for all the strains tested. Five enzyme tests were negative, while two reactions showed inconsistent results. Because this test is semi-quantitative, no attempt was made to measure the intensities of the colored reaction products spectrophotometrically. Therefore, the reactions were recorded as positive, negative or variable. The differences in the gaseous environments did not have any effect on the semiquantitative enzyme profile of the treponemes.

\section{Quantitative enzyme determinations}

A total of ten to twelve separate cultivations of the cells of $T$. denticola ATCC 35405 were carried out in both gaseous environments, followed by detailed determination of specific peptidase and oxidoreductase activities. Table II summarizes the specific peptidase activities determined with cell extracts of the treponemes. Although the overall results indicated a certain type of inconsistency in the hydrolysis of several peptidase substrates, it appeared that the specific activities calculated for pro-2-NA were consistently higher when tested with extracts from anaerobic cultures than fiom acrobic cultures. Another consistent observation was that the hydrolysis of BANA and BAFNA showed no such differences in culture conditions. The rate of the hydrolysis of PZ-PLGPA was higher in five clinical isolates when tested with extracts from anaerobic cultures (not shown). These 

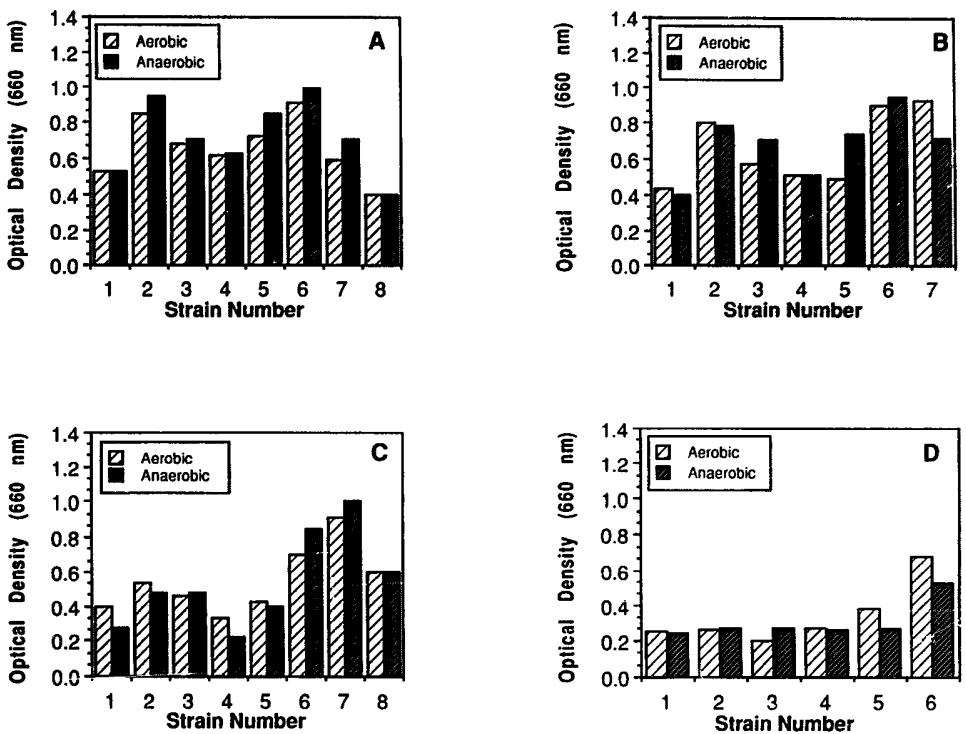

Fig. 1. Growth of $T$, denticola ATCC 35405 (strain i) and its clinica! isolates (numbered from 2 to 8) under various chemical culturing conditions.

Panel A: growth in an aerobically maintained broth (O broti); Panel B: growth in a freshly prepared broth (F broth); Panel $\mathrm{C}$ : growth in a prereduced broth ( $\mathrm{R}$ broth); Panel $\mathrm{D}$ : growth in a medium (NS) without supplement addition. Definition of strains: $2=\mathrm{H}_{21} ; 3=\mathrm{Al}_{2} ; 4=$ Spira; $5=\mathrm{Myr} ; 6 \mathrm{H}_{1} ; 7=$ Corha $; 8=\mathrm{Sim}_{2}$. The values shown are means of duplicate experitnents.

studies thus indicated that the degree of aerobicity had a selective effect on the relative peptidase levels; the proline iminopeptidase activity of these treponemes depended on the nature of the gaseous atmosphere while the so-called BANA-peptidase production was virtually insensitive to such differences in culturing conditions.

Repeated FPLC separations on both the anion exchange and gel columns showed that these differences in enzyme activities were predominantly quantitative. Consequently, all cell extracts that exhibited higher peptidase activity after anaerobic culturing yieided, in FPLC separations, the same number of enzyme and protein "peaks" as the extracts from aerobic culturing. In cases where the crude extract showed higher activit $\%$, the resulting FPLC chromatograms also exhibited higher enzyme "peaks". Therefore, the results of the above quantitative enzyme determinations were verified in the FPLC studies. These experiments demonstrated that the degree of aerobicity as tested in this 
Table I. Biochemical reactions of $T$. denticn!s ATCC 35405 and of seven $T$. denticola clinical isolates tested by means of the rapid enzyme profile test, and other reactions (Syed et al., 1984, 1985) under aerobic (A) and anaerobic (B) conditions.

Substrate used or test performed $\quad \begin{gathered}\text { Result } \\ \text { A N N }\end{gathered}$

Glycosidase reactions:

$p$-Nitrophenyl- $\alpha$-D-galactopyranoside $\quad++$

$p$-Nitrophenyl- $\alpha$-L-fucopyranoside - -

p-Nitrophenyl- $\beta$-D-xylopyranoside - -

$p$-Nitrophenyl- $\alpha$-D-glucopyranoside ++

$p$-Nitrophenyl- $N$-acetyl- $\beta$-D-glucosaminide -

6-Bromo-2-naphthyl- $\beta$-D-galactopyranoside ++

6-Bromo-2-naphthyl- $\beta$-D-glucopyranoside ++

Peptidase reactions:

$N_{\alpha}$-L-prolyl-2-naphthylamine

$N \alpha$-L-seryl-2-naphthylamine

$N \alpha$-L-pyrrolidonyl-2-naphthylamine

$N \alpha$-L-arginyl-2-naphthylamine

$\mathrm{N \alpha}$-L-Lysyl-2-naphththylamine

$N \alpha$-L-hydroxyprolyl-2-naphthylamine

$N \alpha$-benzoyl-DL-arginyl-2-naphthylamine

$\mathrm{N} \alpha$-L-glutamyi-4-methoxy-2-naphthylamine

$\mathrm{Na}$-glycylglycyl-2-naphthylamine

Other reactions:

Esculin hydrolysis

Indole production

Nitrate reduction

Catalase reaction

$+=$ positive reaction with all strains: $-=$ negative reaction with all strains: $\pm=$ variable reactions. study had no detectable qualitative effect on the protein and enzyme profiles on FPLC columns. An example of these studies is shown in figure 2, which demonstrate the clearly increased activity of the iminopeptidase(s) involved in an extract obtained from an anaerobic experiment. These quantitative enzyme studies thus revealed differences between enzyme activities that semiquantitative tests failed to demonstrate.

The studies of the SOD and catalase activities showed that the cell suspensions of $T$. denticola ATCC 35405 and the toluene-treated cells exhibited measurable enzyme levels (table III). It appeared that toluene treatment is a suitable procedure for the detection of SOD activity in the whole cells of this spirochete. The catalase activity of the whole cells was considered low, varied and inconsistent. Several experiments showed no catalase activity present in the suspension of washed cells. Based on the procedures developed in preliminary studies, the enzymes obtained from the above clinical isolates, cultivated aerobically and anaerobically, were next tested for SOD, catalase, and also for peroxidase activity. The enzymes were prepared by treating the cells with ultrasound or with a mild SDS solution (1.4 mM SDS for $50 \mathrm{mg}$ cells, wet weight, in $3.5 \mathrm{ml}$ ). These studies showed that the activity of SOD was slightly higher in extracts from anaerobically grown cells, compared with aerobically grown cells. The activity of peroxi-

Table II. Specific peptidolytic activity (in $\mu$ moles per time unit and $\mathrm{mg}$ ) of the cell extracts of $T$. denticola ATCC 35405 determined with seven substrates.

Substrate

A

N

\begin{tabular}{|c|c|c|}
\hline 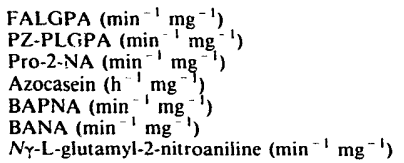 & $\begin{array}{l}0.62 \pm 0.48 \\
0.16 \pm 0.08 \\
2.06 \pm 0.75 \\
0.41 \pm 0.26 \\
0.47 \pm 0.26 \\
0.13 \pm 0.09 \\
0.034 \pm 0.030\end{array}$ & $\begin{array}{c}0.66 \pm 0.57 \\
0.20 \pm 0.09 \\
2.80 \pm 0.81 \\
0.51 \pm 0.16 \\
0.47 \pm 0.27 \\
0.14 \pm 0.08 \\
0.037 \pm 0.033\end{array}$ \\
\hline
\end{tabular}

\footnotetext{
The extracts were obtained from cells grown to a stationary phase under acrobic $(A)$ and anacrobic $(N)$ conditions, and treating the cells with an ultrasonic disintegrator, foilowed by cenirifugation for $10 \mathrm{~min}$ at $10,000 \mathrm{~g}$. The cultivations and the subsequent cell treatments and enzyme determinations were carried out seven times. The values shown are means \pm SD $(n=10-12$ except for PZ-PLGPA and BANA, for which the value of $n$ was 4 and 5 , respectively). The rates of the hydrolysis of pro-2-NA differed significantly between $A$ and $N$ ip $<0.05$ in paired $t$ test).
} 


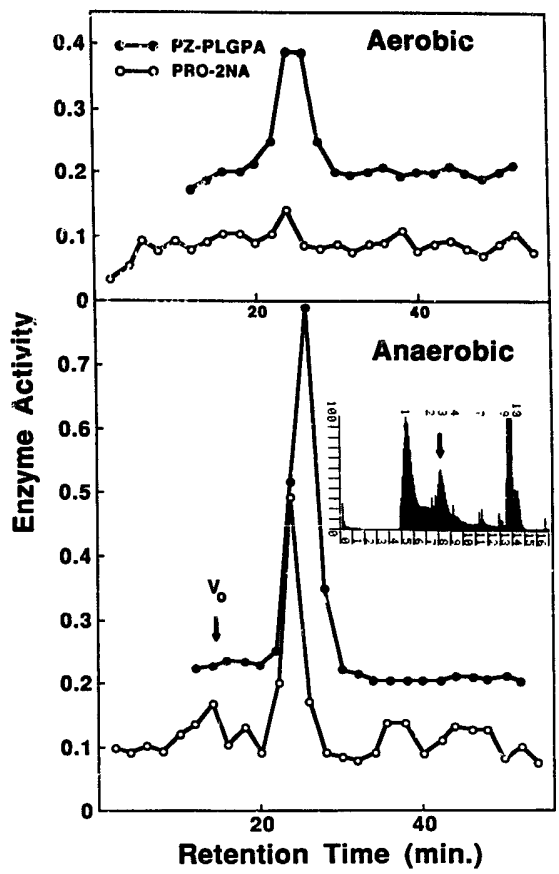

Fig. 2. FPLC on a Superose 6 gel filtration column of the cell extracts of $T$. denticola (strain $\operatorname{Sim}_{2}$ ), obtained from an aerobic and an anaerobic cultivation.

Four hundred $\mu l$ of filtered sample were injected in both cases into the coluinn which was eluted with $10 \mathrm{mM}$ Tris- $\mathrm{HCl}(\mathrm{pH} 7.0$, containing $100 \mathrm{mM} \mathrm{NaCl}$ and $1.0 \mathrm{mM} \mathrm{CaCl}$ ) at a flow rate of $0.5 \mathrm{ml} / \mathrm{min}$. The fractions $(1.0 \mathrm{ml})$ were tested for PZ-PLGPA-hydrolysing enzymes and tor iminopeptidase activity using pro--2NA as substrate. The void volume tor $\left(\mathrm{V}_{0}\right)$ is indicated. The insert shows the separation of proteins, which was identical in both cases. The arrow in the insert shows the protein peak which coincided with the enzyme peaks.

dase was very low and associated with the precipitable cell fragments. Because of the very low enzyme activity, the clinical strains could not be studied for peroxidase. The enzyme(s) responsible for the SOD activity of these treponemes could be soluble; this activity was detectable both in cell-free extracts and in the outer envelope fractions. The low and varied catalase activities did not render more quantitative studies possible. 
Table III. Activity of SOD and catalase in various cell preparations of $T$. denticola ATCC 35405 .

\begin{tabular}{lcc} 
Cell preparation & $\begin{array}{c}\text { SOD activity } \\
\text { (units/mg) }\end{array}$ & $\begin{array}{c}\text { Catalase activity } \\
\text { (units/mg) }\end{array}$ \\
\hline Cell suspension $(20-30 \mathrm{mg}$ cells/ml) & 1.0 & $4-14.7$ \\
After 5 -min toluens treatment & 2.0 & $1.6-40$ \\
After I-min toluene treatment & 3.6 & $4-40$ \\
Cell-free extract & 3.5 & $0-2.7$ \\
Dialysed cell-free extract & 0.6 & $\mathrm{nil}$ \\
\hline
\end{tabular}

\section{DISCUSSION}

This study demonstrated two points: it was observed for the first time that $T$. denticola is a facultatively anaerobic, host-associated spirochete that is capable of growth under anaerobic and acrobic conditions. This observation is in contrast to reports suggesting that this organism is an obligate anaerobe (Smibert. 1984,1985 ). The growth yields of the cells as judged by optical density data were similar or even higher under acrobic conditions compared with anaerobic conditions. It also became evident that the gaseous environments used had no detectable effict on the microscopic morphology and motility of the cells, nor was the semiquantitative enzyme profile of the cells (as tested with the present rapid test system) affected. These observations imply that the metabolic pathways related to the synthesis of major (enzyme) proteins were not affected by differences between the gaseous conditions. This was confirmed by SDS-PAGE analyses of the cell extracts (Syed et al., 1991). The second important point demonstrated was the selectivity of the effect of the gaseous growth environments on the levels of certail peptidolytic enzymes, as shown by quantitative enzyme studies. The gaseous environments tested obviously had no remarkable effect on most of the present enzyme activities, but the selectivity of some effects was still evident : iminopeptidase activity, and to a certain extent, the activity of an enzyme (or enzyniss) hydrolysing PZ-PLGPA, tended to be higher in cells grown anaerobically. On the other hand, we were unable to detect any such trend in the hydrolysis of BANA and BAPNA. Therefore, the iminopeptidase and BANA peptidase levels were quite differently affected by the two gaseous growth environments tested. It cannot be expected that such differences would be reflected in SDS-PAGE electrophoretograms of cell extracts, because the enzyme proteins in question must represent a small portion of total stainable proteins present. The selective effect of the gaseous growth environments should be examined in light of the fact that proline iminopeptidases have been considered "dominant" peptidases of $T$. denticola ATCC $3540 \hat{5}$ (Mäkinen et al., 1987), and that the so-called BANApeptidase activity constitutes the biochemical rationale of a diagnostic enzyme test in periodontology (Loesche et al., 1990). It is important to emphasize that qualitative or semi-quantitative enzyme tests may fail to detect this type of selective effect of the gaseous growth environment on cellular enzyme levels. However, the present semi-quantitative findings per se are in agreement with data obtained on $T$. denticola strains using the same semi-quantitative procedure (Syed et al., 1988). Mikx (1991) also reported comparable results regarding the peptidase and glucosidase activity of $T$. denticola, determined with the rapid enzyme profile system. The relatively high batch-to-batch variation in enzyme activities (table II) can be regarded as a net effect of the several preparatory procedures involved, such as inoculation, cultivation, enzyme extraction, assay conditions, etc. In spite of this variation, it became evident that the gaseous 
environment did exert a selective effect on the peptidase activities studicd.

Because none of the three oxidoreductase enzymes tested in this study exhibited any strong or consistent dependency on the nature of the gaseous growth environment, it may be coincluded that at least one single 7-day exposure of the cells to those different gaseous conditions was unable to elicit significant changes on the rater, these enzymes were formed, or on the activity levels of these enzymes. It is possible that continued, long-term exposure would induce more significant changes in oxidoreductase. levels. Also, it is possible that other oxidoreductases (such as EC 1.1.1, i.e. those acting with NAD ${ }^{+}$ or $\mathrm{NADR}^{+}$as acceptors, and $\mathrm{EC}$ 1.1.3, i.e. those acting with oxygen as acceptor) would react differently compared with catalase, peroxidase and SOD.

Fiehn and Westergaard (1986) reported that the small-size spirochetes resembling $T$. denticola could be grown on solid agar media in gaseous environments containing up to $2 \%$ oxygen. Although we did not attempt to grow the cells on agar media, our studies constantly showed that the cells of $T$. denticola grew well in room atmosphere in either reduced or oxidized broth, suggesting that the oxidation-reduction potential of the medium may not be as significant a factor as has been assumed. Therefore, certain essentiai growth supplements - rather than the nature of the gaseous environment - seemed to have a profound effect on the growth yield of this organism. It has been consistently shown in this laboratory that the cells of several strains of $T$. denticola always grow as subsurface colonies in prereduced agar media even if they are grown in strictly anaerobic conditions. The significance and reasons for this characteristic growth in a continuous anaerobic environment are not known. The cells grown aerobically or anaerobically consistently exhibited uniform turbidity in this study both in small and large volumes of broth. These findings suggest that $T$. denticola is a facultatively anaerobic orgañinism and not an obligate anaerobe. Further indepth studies are required to re-establish the position of this organism in regard to its relationship to oxygen.

\section{Acknowls:dgements}

This study was supported in part by grant \# DEO8664 and DEO2731-19 from the National Institute for Dental Res:arch, and from sevcral grants from Cultor, Helsinki, Fisiland.

\section{Peptidohydrolases et oxydoréductases de Treponema denticola ATCC 35405 en aérobiose et en anaérobiose}

En parallèle avec la croissance de Treponema denticola ATCC 35405 en fonction de la composition du milicu de culture, les profils des peptidohydrolases et des oxydoréductases (catalase, peroxydase, superoxyde dismutase) ont été établis en fonction des conditions d'aérobiose ou d'anaérobiose. Une synthèse accrue de la proline-iminopeptidase apparaît liée à l'aérobiose. L'activité des oxydoréductases apparaît basse, variable, et par conséquent peu liée à la composition de l'atmosphère. L'analyse des conditions de croissance de $T$. denticola, isolè notamment des plaques dentaires, montre que ce spirochète est un anaérobie facultatif (et non obligatoire comme l'affirmait la littérature jusqu'à ce jour).

Mots-clés: Oxygène, Stomatologie, Treponema denticola; Protéas es, Oxydoréductases, Atmosphère gazeuse, Odontologie.

\section{Referenc 3}

Barron S.L., Riviere, G.R., Simonson, L.G., Lukehart, S.A., Tira, D.E. \& O'Neil, D.W. (1991), Use of nonoclonal antibodies to enumerate spirochetes and identify Treponema denticola in dental plaque of children, adolescents and young adults. Oral Microbiol. Immunol., 6, 97-101.

3radford, M.M. (1976), A rapid and sensitive method for the quantitation of microgram quantities of protein utilizing the principle of protein-dye binding. Anal. Biochem., 72, 248-254.

Elstner, E.F., Youngman, R.J. \& Osswald, W. (1983), in "Methods of enzymatic analysis Vol. Ill, 3rd edn." (H.V. Bergmeyer) (pp. 293-302). Academic Press, New York.

Fiehn, N.E. \& Westcrgaard, J. (1986), Nutrient and environmental growth factors for eight small-sized spirochetes. Scand. J. Dent. Res., 94, 208-218.

Grenier, D., Uit to, V.-J. \& McBride, B.C. (1990), Cellular location of a Treponema denticola chymotrypsinlike protease and importance of the protease in migration through the basement membrane. Infect. Immun., 58, 347.351.

Gusberti. F.A. \& Syed, S.A. (1984), Development of a ministurized nitrate reduction test for the identification of oral bacteria. J. Microbiol. Meth., 2, 333-338. 
Hendrickson, D.A. (1985), Reagents and stains, in "Manual of clinical microbiology, 4th edn." (E.H. Lennette, A. Balows, W.J. Hausler, Jr \& Shadomy) (p. 1095). Amer. Soc. for Microbiol., Washington, DC.

Holt, S.C. \& Bramanti, T.E. (1991), Factors in virulence expression and their role in periodontal disease pathogenesis. Crit. Rev. Oral Biol. Med., 2, 177-281.

Karim, R.M., Qadri, S.M.H. \& Flournoy, D.J. (1981), A rapid method for the detection of tryptophanase in anaerobic bacteria. Antonie van Leeuwenhoek, 47, 499-507.

Lnesche, $W . J .(1988)$, The role of spirochetes in peridontal disease. Adv. Dent. Res., 2, 275.283.

Loesche, W.J.. Bretz, W.A., Kerschensteiner, D., Stoll, J., Sociansky, S.S., Hujoel, P. \& Lopatin, D.E. (1990). Development of a diagnostic test for anaerobic periodontal infections based on plaque hydrolysis of benzoyl-DL-arginine-naphthylamide. J. Clin. Microbiol., 28, 1551-1559.

Mäkinen, K.K., Mäkinen, P.-1. \& Syed, S.A. (1992), Purification and substrate specificity of an endopeptidase from the human oral spirochete Treponema denticola ATCC 35405, active on furylacryloyl-leugly-pro-ala and bradykinin. J. Biol. Chem., 267, 14285-14293.

Mäkinen, K.K., Syed, S.A., Loesche, W.J. \& Mäkinen, P.-L. (1988), Proteolytic profile of Treponema vincentii ATCC 35580 with special reference to collagenolytic and arginine aminopeptidase activity. Oral Microbiol. Immunol., 3, 121-128.

Mäkinen, K.K., Syed, S.A., Mäkinen, P.-L. \& Loesche, W.J. (1987), Dominance of iminopeptidase activity in the human oral bacterium Treponema denticola ATCC 35405. Curr. Microbiol., 14, 341-346.

Mäkinen, K.K., Syed, S.A., Salvador, S.L. \& Mäkinen, P.-L. (1990), Hydrolysis of the leu-gly bond of phenylazobenzyloxycarbonyl-L-leu-gly-L-pro-D-arg (a substrate of microbial collagenases) by treponemes isolated from the subgingival plaque of periodontitis patients. Curr. Misobiol., 20. 69-74.

McCord, J.M. \& Frifovich, I. (1969), Superoxide dismutase. An enzymatic function for erythrocuprein. J. Biol. Chem., 244, 6049-6055.

Mikx, F.H.M. (1991), Comparison of peptidase, glycosidase and esterase activities of oral and nonoral Treponema species. J. Gen. Microbiol., 137, 63-68.

Pine, L., Hoffman, P.S., Malcom, G.B., Benson, R.F. \& Kea, A.G. (1984), Determimation of catalase, peroxidase, and superoxide dismutase within the genus Legionella. J. Clin. Microbiol., 20, 421-429.

Qadri, S.M.H., DeSilva, M.I. \& Zubairi, S. (1980), Rapid test for determination of esculin hydrolysis. J. Clin. Microbiol., 12, 472-474.
Que, X.-C. \& Kuramitsu, H.L. (1990), Isolation and characterization of the Treponema denticola prtA gene coding for chymotrypsinlike protease activity and detection of a closely linked gene encoding PZPLGPA-hydrolyzing activity. Infect. Immun., 58, 4099.5105.

Riviere, G.R., Elliot, K.S., Adams, D.F., Simonson, L.G., Forgas, L.B., Nilius, A.M. \& Lukehart, S.A. (1992), Relative proportions of pathogen-related oral spirochetes (PROS) and Treponema denticola in supragingival plaque from patients with periodontitis. Periodontol., 63, 131-136.

Russel, R.R.B. (1992), Bacteriology of Periodontal Dissase. Curr. Opin. Dent. 2, 3, 66-71.

Salvador, S.L., Syed, S.A. \& Loesche, W.J. (1988), Comparison of three dispersion procedures for quantitative recovery of cultivable species of subgingival spirochetes. J. Clin. Microbiol., 25, 2230-2232.

Simonsin, L.G., Goodman, C.H. Bial, J.J., Morton, H.E. (1988), Quantitative relationship of Treponemta denticola to severity of periodontal disease. Infect. Immun., 56, 726-728.

Smibei, R.M. (1984), Genus IIl Treponema Schaudinn $1905,1728 \mathrm{AL}$, in "Bergey's manual of systematic bacteriology, Vol. I" (N.R. Krieg, R.J. Holt) (pp. 49-57). Williams and Wilkins, Baltimore.

Smibert, R.M. (1985), Anaerobic spirochetes, in "Manual of clinical microbiology, 4th editicn" (E.H. Lennette, A. Balows, W.J. Hausler, Jr \& H.J. Shadomy) (pp. 489-494). Amer. Soc. for Microbiol., Washington, DC.

Syed, S.A., Gusberti, F.A., Loesche, W.J. \& Lang, N.P. (1984), Diagnostic potential of chromogeric substrates for rapid detection of bacterial enzymatic activity in health and disease associated periodontal plaques. J. Periodont. Res., 19, 618-621.

Syed, S.A., Loesche, W.J. \& Flynn, M. (1985), Comparison of two rapid systems for characterization of subgingival bacteria. IADR Abstract No. 155. J. Dent. Res., (special issue) 64, 192.

Syed, S.A., Salvador, S.L. \& Loesche, W.J. (1988), Enzyme profiles of oral spirochetes in rapid ANA system. J. Clin. Microbiol., 26, 2226-2223.

Syed, S.A., Muhammad, Z., Lopatin, D.E. \& Kristoffersen, T. (1991), Protein patterns of T. denticola grown in various gaseous environmeits. Abstract No, 2511 . J. Dent. Res., (special issue) 70, 580.

Uitto, V.-J., Haapasalo, M., Laakso, T. \& Salo, T. (1988), Degradation of basement membrane collagen by proteases from some anaerobic oral microorganisms. Oral Microbiol. Immunol., 3, 97-102.

Whitelam, G.L. \& Codd, G.A. (1982), A rapid whole-cell assay for superoxide dismutase. Anal. Biochem., 121, 207-212. 